\title{
The Effectiveness of Ketumpang Air (Peperomia pellucida) to Reduce the Impact of Edema Using Smilax sp.
}

\author{
Sirojjuddin $^{1}$, Aldila Mawanti Athirah ${ }^{2, *}$, Nurhidayah Syarifuddin ${ }^{3}$, Nurfitri Rahim ${ }^{4}$, Rizal Chandra \\ Maulana $^{2^{*}}$

\begin{abstract}
${ }^{1}$ Department of Biology Education, Education University of Muhammadiyah Sorong, 98457, Sorong, Papua Barat
${ }^{2}$ Departement Agribusiness, Education University of Muhammadiyah Sorong, 98457, Sorong, Papua Barat

${ }^{3}$ Department Pharmacy, Education University of Muhammadiyah Sorong, 98457, Sorong, Papua Barat

${ }^{4}$ Department Aquaculture, Education University of Muhammadiyah Sorong, 98457, Sorong, Papua Barat *Corresponding Author: sirojijuddin@unimudasorong.ac.id; aldila.athirah@gmail.com
\end{abstract}

Copyright@ 2021 by authors, all rights reserved. Authors agree that this article remains permanently open access under the terms of the Creative Commons Attribution License 4.0 International License

\begin{abstract}
The purpose of this research was to determine the effectiveness of Ketumpang Air (Peperomia pellucida) to reduce the impact of edema caused by Smilax sp. This research was conducted in the integrated laboratory of the Muhammadiyah Education University (UNIMUDA) Sorong. The variables of this research were Ketumpang Air as the independent variable and the impact of Smilax sp. as the dependent variable. The results showed that the giving of Ketumpang air had a significant effect in reducing edema caused by the use of Smilax sp. with a significance level of $5 \%$ is 0.00089 .
\end{abstract}

Keywords Peperomia pellucida, Smilax sp., Edema

\section{Introduction}

Papua has a very complex diversity of living things from flora to fauna [1] which is a combination of the continents of Asia and Australia [2]. One of the biodiversity found in Papua and West Papua is medicinal plants [3]. There are more than $50 \%$ of medicinal plants given by Papua land to Indonesia until now and still unknown and a mystery in the Papuan forests [4][5].

Some of the medicinal plants commonly used by people in Papua and West Papua include Laportea sp. [6], Piper methysticum L [7], Phaleria macrocarpa) [8], Myrmecodiatu berosa Jack. /Rubiaceae) [9], Piper crocatum Ruiz \& Pav./ Piperaceae [10] and Smilax sp. [11] and Sirih China/Ketumpang Air (Peperomia pellucida)[12] .

Ketumpang Air or Sirih China also Latin named Peperomia pellucida is a plant with a height of $6-45 \mathrm{~cm}$ with an upright base stem, but sometimes striated, epiphytic (plants that can grow with other plants, without taking nutrients from the plants they are on). The leaves are of equal length with a width of about $0.3-4 \mathrm{~cm}$, petiole round with longitudinal furrows about $0.1-0.7 \mathrm{~cm}$ long, fleshy, oval, triangular, leaves wide at the base and conical at the ends with a whole edge, 3-5 leaf veins from the base of the flower grow vertically upwards in the opposite direction to the growth of the leaves, with a length of about $0.8-9.2 \mathrm{~cm}$ (Mohd Zamri et al. 2020), and live in humid areas [13]

Extracts of this medicinal plant contain various chemical constituents such as alkaloid, flavonoid, saponin, tannin, dan triterpenoid [14]. The various benefits of this plant include treating diseases such as burns and hits, kidney disease, headaches, and fever [15]. In addition, this Ketumpang Air/Sirih China also contains antihiperglikemik [16], which can reduce glucose and uric acid levels [17], while the gel from this plant can heal burns [18] and has antibacterial inhibiting development Aeromonas hydrophila, Edwardsiella tarda, Escherichia coli, 13 Flavobacterium sp., Klebsiella sp., Pseudomonas aeruginosa, Salmonella sp., Vibrio alginolyticus, Vibrio cholera, Vibrio parahaemolyticus [19].

Smilax sp. is one of the medicinal plants from Papua, both Papua and West Papua. This plant is usually used as a traditional medicine to enlarge the male genitalia which previously experienced edema/swelling [20]. This edema can occur due to enlarged pores, fluid in the subcutaneous tissue [11].

Based on the description above, we are interested in conducting a research entitled the effectiveness of Ketumpang Air (Peperomia pellucida) to reduce the impact of edema using Smilax sp. However, in use, if you don't follow proper procedures, you will get serious injuries and have to get hospitalized [21].

Edema is swelling of the tissue due to increased fluid content [22]. This can occur due to excess fluid contained in certain body tissues [23]. Associated with the use of Smilax sp., this swelling occurs in the skin pores and triggers an increase in hair follicles [11]. Smilax sp. or often called by the people of Papua, this leaf wrap or leaf of three fingers contains vitamin, mineral, amino acid and sulfuric acid, and polyphenol [21]

Traditional medicines are medicines that are obtained 
from generation to generation by oral tradition and can be obtained in the wild [24]. Meanwhile, according to the Ministry of Health of the Republic of Indonesia, it is a mixture of ingredients in the form of plant materials, animal ingredients, mineral materials, sarian (galenic) preparations, or mixtures of these materials which have been used for generations for treatment, and can be applied according to the norms prevailing in society. [25].

This is very important to do to determine the effectiveness of Peperomia pellucida in reducing edema caused by Smilax sp. because many Papuan people use Smilax sp. to enlarge their genitals, many of which die due to rupture of blood vessels in their genitals.

\section{Materials and Methods}

The type of research conducted is experimental research. Experimental research is research that aims to find cause and effect [26]. The application of this research uses Femus galusgalus (broilers) as the research object. The design framework for this research is as follows:

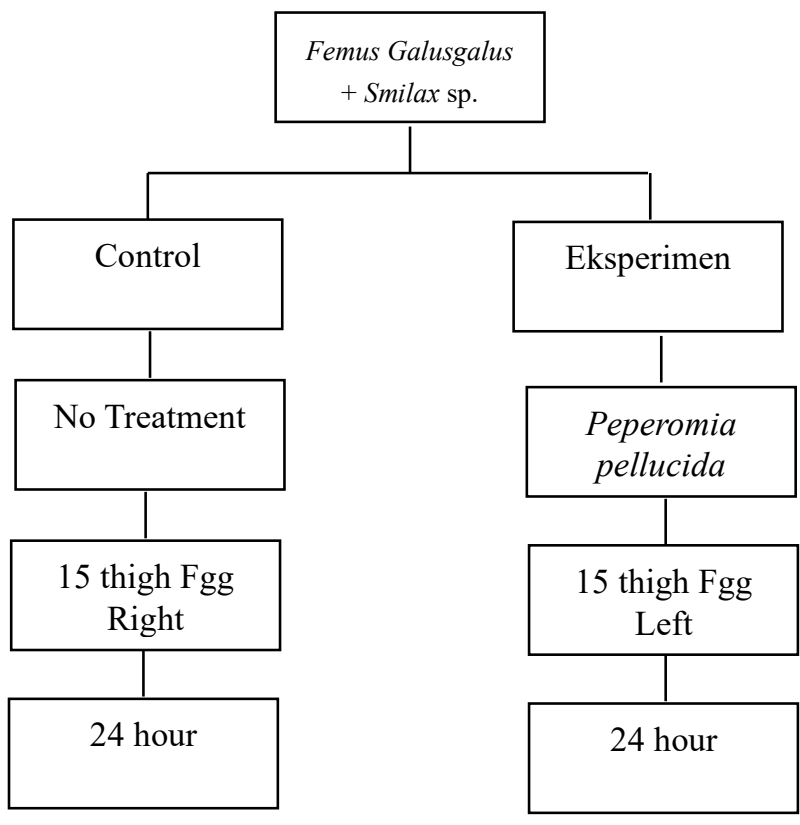

Figure 1. Design Framework Research

The population of this research is a traditional medicine with the sample is Peperomia pellucida, Smilax sp., and Femus galusgalus. The techniques and instruments of this research are observation and documentation. The tools used are analytical balance, caliper, and camera. Some of the materials used in this research are Peperomia pellucida, Smilax sp., and Femus galusgalus

\section{Discussion}

Based on normality test of thigh size data on Femus galusgalus shows that based on the formulation of Kolmogorov-Smirnova for the diameter has a significant value on the use of Peperomia pellucida and Smilax sp. of
0.200, while the calculation with Shapiro-Wilk the use of Peperomia pellucida of 0.303 and on the use of Smilax sp. of 0.112 . This shows that the results of the data distribution are normally distributed.

Comparison of the thigh size of Femus galusgalus (Fgg) before and after the use of Smilax sp., after being treated with 10 grams of Smilax sp., and for 24 hours, as follows:

Table 1. Size of Thighs Fgg before and after use of Smilax sp.

\begin{tabular}{ccc}
\hline Sample & $\begin{array}{c}\text { Diameter of } \\
\text { Thighs Fgg } \\
\text { Before giving } \\
\text { Smilax sp. }\end{array}$ & $\begin{array}{c}\text { Diameter of } \\
\text { Thighs Fgg } \\
\text { after giving } \\
\text { Smilax sp }\end{array}$ \\
\hline A1 & 2,4 & 3,01 \\
\hline A2 & 2,5 & 3,2 \\
\hline A3 & 2,66 & 3,2 \\
\hline A4 & 2,05 & 2,6 \\
\hline A5 & 2,49 & 3,12 \\
\hline A6 & 2,29 & 3,08 \\
\hline A7 & 2,11 & 2,87 \\
\hline A8 & 2,12 & 2,5 \\
\hline A9 & 2,44 & 3,2 \\
\hline A10 & 2,41 & 3,19 \\
\hline A11 & 2,2 & 2,8 \\
\hline A12 & 2,63 & 3,1 \\
\hline A13 & 2,1 & 2,7 \\
\hline A14 & 2,51 & 2,95 \\
\hline A15 & 2,45 & \begin{tabular}{c} 
S,36 \\
\hline Aean
\end{tabular} \\
\hline
\end{tabular}

Graph of average increase/mean size of thigh Fgg when using Smilax sp. as stated in the following graph: 


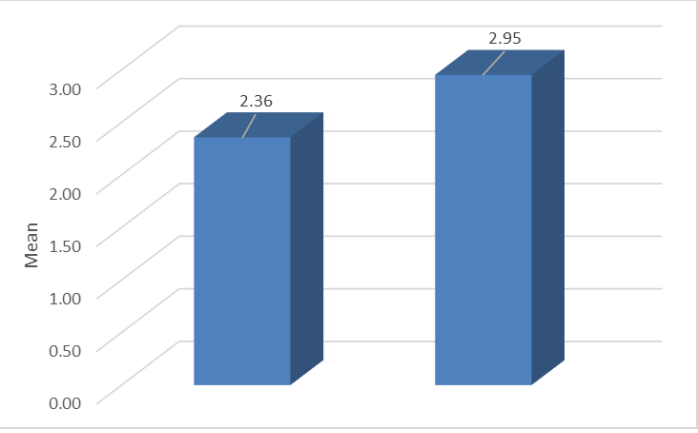

Figure 2. Mean size of thigh Fgg using Smilax sp.

Data on the effect of using Ketumpang Air on edema caused by smilax sp., with doses of $10 \mathrm{~g}, 20 \mathrm{~g}, 30 \mathrm{~g}, 40 \mathrm{~g}$, and $50 \mathrm{~g}$, each treatment 3 times. Right thigh as control left thigh as an experiment.

Table 2. The effect of using Ketumpang Air on edema caused by Smilax sp

\begin{tabular}{c|c|c|c}
\hline Sample & $\begin{array}{c}\text { Dose } \\
\text { (g) }\end{array}$ & $\begin{array}{c}\text { Thigh } \\
\text { Diameter Fgg } \\
\text { which has } \\
\text { Edema } \\
\text { due to Smilax } \\
\text { sp. }\end{array}$ & $\begin{array}{c}\text { Thigh Diameter } \\
\text { Fgg Decreased } \\
\text { Edema due to } \\
\text { Ketumpang Air }\end{array}$ \\
\hline A1 & 10 & 2,6 & 2,56 \\
\hline A2 & 10 & 3,14 & 3,08 \\
\hline A3 & 10 & 3,17 & 3,01 \\
\hline A4 & 20 & 2,75 & 2,11 \\
\hline A5 & 20 & 2,6 & 2,57 \\
\hline A6 & 20 & 2,84 & 2,46 \\
\hline A7 & 30 & 2,73 & 2,13 \\
\hline A8 & 30 & 2,46 & 2,2 \\
\hline A9 & 30 & 2,9 & 2,7 \\
\hline A10 & 40 & 3,01 & 2,55 \\
\hline A11 & 40 & 3,09 & 2,46 \\
\hline A12 & 40 & 3,15 & 2,92 \\
\hline
\end{tabular}

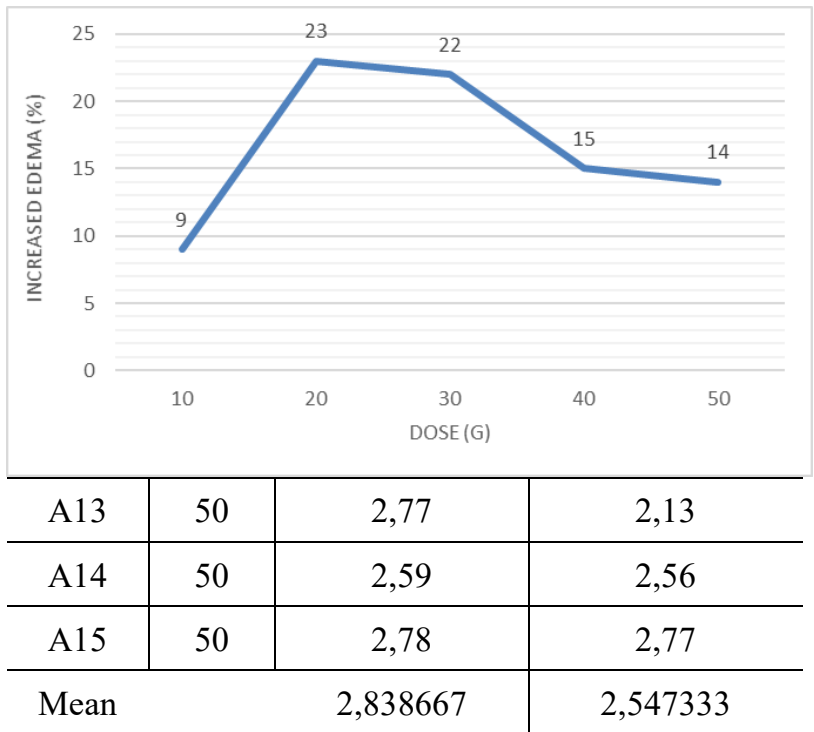

Based on the data above, the dose effectiveness of using Ketumpang Air is shown in the following graph:

Figure 3. Graph of the Effectiveness of using Smilax sp. Dosage

Based on the graph, the most effective dose is $20 \mathrm{~g}$ with $23 \%$ increase in edema percentage.

Size comparison before used of Smilax sp. and after use of Ketumpang Air as described in the following Table 3:

Table 3. Size comparison before use of Smilax sp. and after use of Ketumpang Air on Fgg

\begin{tabular}{|c|c|c|c|}
\hline Sample & $\begin{array}{c}\text { Before being } \\
\text { given smilax } \\
\text { sp. }\end{array}$ & $\begin{array}{l}\text { After being } \\
\text { given } \\
\text { Ketumpang } \\
\text { Air }\end{array}$ & $\begin{array}{c}\text { The Difference } \\
\text { Between Given } \\
\text { smilax sp. and } \\
\text { After Given } \\
\text { Ketumpang Air }\end{array}$ \\
\hline A1 & 2,4 & 2,56 & $6 \%$ \\
\hline $\mathrm{A} 2$ & 2,5 & 3,08 & $19 \%$ \\
\hline A3 & 2,66 & 3,01 & $12 \%$ \\
\hline A4 & 2,05 & 2,11 & $3 \%$ \\
\hline A5 & 2,49 & 2,57 & $3 \%$ \\
\hline A6 & 2,29 & 2,46 & $7 \%$ \\
\hline A7 & 2,11 & 2,13 & $1 \%$ \\
\hline A8 & 2,12 & 2,2 & $4 \%$ \\
\hline A9 & 2,44 & 2,7 & $10 \%$ \\
\hline A10 & 2,41 & 2,55 & $5 \%$ \\
\hline
\end{tabular}




\begin{tabular}{cccc}
\hline A11 & 2,2 & 2,46 & $11 \%$ \\
\hline $\mathrm{A} 12$ & 2,63 & 2,92 & $10 \%$ \\
\hline $\mathrm{A} 13$ & 2,1 & 2,13 & $1 \%$ \\
\hline $\mathrm{A} 14$ & 2,51 & 2,56 & $2 \%$ \\
\hline $\mathrm{A} 15$ & 2,45 & 2,77 & $12 \%$ \\
\hline Mean & 2,36 & 2,55 & $7 \%$ \\
\hline
\end{tabular}

level of $5 \%$, the existing sample concludes that there is a significant effect between the intercept value on reducing edema, which is indicated by a P-value of 0.000651 . Then Ketumpang Air (X) has a significant effect on edema caused by smilax as shown by the p-value value of 0.000898 .

Based on the statistical regression test, the R-Square value is 0.584746 , which means that Ketumpang Air affects the decrease in edema by $58.47 \%$ and the rest is influenced by other variables. These results are illustrated in the following summary of the regression statistical tests:

Based on these data, it was proven that there was a decrease in the size of the Fgg thighs after being given water by $7 \%$, from the initial impact due to the use of Smilax sp. which resulted in swelling of 23\% (in Figure 3).

It is also in line with the results of the hypothesis test using Anova which shows that Ketumpang Air is effective in reducing edema caused by Smilax sp., with a significant level of $5 \%$ and a significance level of 0.00089 , as illustrated in the following Table 4:

Table 4. ANOVA

\begin{tabular}{lllllc}
\hline & & & & & Significance \\
& $d f$ & SS & MS & $F$ & $F$ \\
\hline Regression & 1 & 0,443456 & 0,443456 & 18,30617 & 0,00089826 \\
Residual & 13 & 0,314917 & 0,024224 & & \\
Total & 14 & 0,758373 & & & \\
\hline
\end{tabular}

This is also supported by a simple regression test, where variable $\mathrm{X}$ (Ketumpang Air) affects variable Y (edema caused by Smilax sp.), as described in the following Table 5:

Table 5. P-value Intercept and Ketumpang Air (X)

\begin{tabular}{|c|c|c|c|c|}
\hline & Coefficients & $\begin{array}{l}\text { Standard } \\
\text { Error }\end{array}$ & t Stat & P-value \\
\hline Intercept & 1,510392 & 0,33917 & 4,453201 & 0,000651 \\
\hline Ketumpang Air (X) & 0,565666 & 0,132209 & 4,278571 & 0,000898 \\
\hline
\end{tabular}

In the table above, it shows that by using a significance

\section{Acknowledgments}

We are very grateful to Directorate General of Higher Education and Culture, Republic of Indonesia, Rector Education University of Muhammadiyah Sorong, Team PKKM (Program Kompetisi Kampus Merdeka) and all of people support us who can't mention one by one.

\section{REFERENCES}

[1] L. K. Ibo and N. Arifa, "Ethnomedicine Of Medicinal Plants Used By Tribal Community In Kaliki Village, Merauke - Papua," Al-Kauniyah J. Biol., 2021, doi: 10.15408/kauniyah.v14i1.15877.

[2] W. Darajati et al., Indonesia Biodiversity Startegy and Action Plan (IBSAP) 2012-2020. 2016.

[3] C. L. Zhang, J. M. Gao, and W. Zhu, "Steroidal saponins from the rhizomes and roots of Smilax scobinicaulis," 
Phytochem. Lett., 2012, doi: 10.1016/j.phytol.2011.09.005. V. Hadju, G. Nature, and S. Makaba, "Etn of Armakologi Plants Ants Nest Papua (Hydnophytum Formicarum) on Skouw Tribe of Papua," Int. J. Res. Med. Heal. Sci., vol. 9, no. 1, 2016.

[5] Universitas Negeri Papua, "Beccariana: Buletin Penelitian Botani/Botanical Reasearch Bulletn." 2001.

[6] E. K. Paisey, Y. Muyan, D. N. Edowai, and M. Dailami, "Genetic Analysis of Itchy Leaves (\&lt;i\&gt;Laportea\&lt;/i\&gt;, sp) in Papua for Herbal Medicinal Products as Development of Studying Economics Value," Nat. Sci., vol. 09, no. 02, pp. 31-41, 2017, doi: 10.4236/ns.2017.92004.

[7] Suharno, R. H. R. Tanjung, S. Sufaati, and V. Agustini, "Wati (Piper methysticum) medicinal plant: The ethnobiological and ethnomedicinal values of the Marind tribe in Merauke, Papua, Indonesia," Biodiversitas, vol. 17, no. 2, pp. 814-822, 2016, doi: 10.13057/biodiv/d170259.

[8] S. N. Setiawan, N. Nurwati, and M. Si, "Dampak COVID19 terhadap Tenaga Kerja di Indonesia," Syeikha Nabilla Setiawan, Nunung Nurwati, M.Si.2, vol. 21, no. April, pp. $1-21,2020$.

[9] M. B. Karo et al., "A mini review of Indonesian medicinal plants for Vulvovaginal candidiasis," Rasayan J. Chem., vol. 10, no. 4, pp. 1280-1288, 2017, doi: 10.7324/RJC.2017.1041887.

[10] Badan Penelitian dan Pengembangan Kesehatan, "Riset Kesehatan Dasar ( Riskesdas ) Provinsi Jawa Barat Tahun 2007," Dep. Kesehat. RI, 2009.

[11] M. Tualeka, "IDENTIFIKASI PROSES Edemi EFEK DARI Smilax Sp,” Biolearning J., 2019, doi: 10.36232/jurnalbiolearning.v5i2.270.

[12] N. A. F. Mohd Zamri, R. Abu Bakar, S. S. Mohd Noor, and W. E. Mohd Fuad, "Antimicrobial Effects of Peperomia Pellucida (Ketumpang Air) Against Multidrug Resistant and Foodborne Organisms Including Toxicity Study in Sprague Dawley Rats," Asian J. Med. Biomed., 2020, doi: 10.37231/ajmb.2020.4.1.320.

[13] Gofur Abdullah, "Tumbuhan Ini Dianggap Gulma, Ternyata Kaya Manfaat,” Mongabay, 2021.

[14] M. Angelina, P. Amelia, M. Irsyad, L. Meilawati, and M. Hanafi, "Karakterisasi Ekstrak Etanol Herba Katumpangan Air ( Peperomia pellucida L . Kunth ) ( Characterization of Ethanol Extract from Katumpangan Air Herbs ( Peperomia)," Univ. Islam Negeri Jakarta, pp. 53-61, 2015.

[15] A. Hariana, 265 Tumbuhan Obat dan Khasiatnya. 2009.

[16] N. Salma, J. Paendong, L. I. Momuat, S. Togubu, T. Suruhan, and K. G. Darah, "Antihiperglikemik Ekstrak Tumbuhan Suruhan ( Peperomia Pellucida [ L .] Kunth ) Terhadap Tikus Wistar ( Rattus Norvegicus L .) Anti Hyperglycemic From Suruhan Plant ( Peperomia Pellucida [ L .] Kunth ) Extract Against Wistar Rats ( Rattus norvegicus L .)," J. Ilm. Sains, vol. 13, no. 2, pp. 116-123, 2013.

[17] N. Yunarto, "EFEK EKSTRAK AIR DAN HEKSAN HERBA SURUHAN Peperomia pellucida (L) Kunth)
TERHADAP PENURUNAN KADAR ASAM URAT SERUM DARAH AYAM KAMPUNG JANTAN," Media Heal. Res. Dev., vol. 23, no. 1, pp. 8-14, 2013, doi: 10.22435/mpk.v23i1.3060.8-14.

[18] T. Luka, B. Pada, K. Oryctolagus, T. Mappa, H. J. Edy, and N. Kojong, "Formulasi Gel Ekstrak Daun Sasaladahan (Peperomia Pellucida (L.) H.B.K) Dan Uji Efektivitasnya Terhadap Luka Bakar Pada Kelinci (Oryctolagus Cuniculus)," Pharmacon, vol. 2, no. 2, pp. 49-56, 2013.

[19] S. Karomah, "UJI EKSTRAK TUMBUHAN SIRIH CINA ( Peperomia pellucida L .) SEBAGAI ANTIBAKTERI TERHADAP BAKTERI Staphylococcus aureus Dan Staphy," 2019.

[20] Syarifudin Labato; Aung Sumbono; Ratna Prabawati, "IDENTIFIKASI AKTIVITAS MOLUSKISIDA LARUTAN Smilax Sp TERHADAP HAMA KEONG MAS (Pomacea Canaliculata Lamarck)," Biolearning J., vol. 06, no. 2, pp. 69-72, 2019.

[21] Aris Wijaya, "Smilax Produksi Putra Papua Dipesan Pasar Lokal dan Internasional," Berempat.com, 2020.

[22] Kamus Bahasa Indonesia Online. 2021.

[23] Widya Citra Andini, "Selain di Kaki, Edema (Pembengkakan) Bisa Terjadi di Bagian Tubuh Apa Saja?," Hallodokter, 24-Sep-2020.

[24] I. M. A. P. Oka, Obat Tradisional. 2016.

[25] Kemenkes RI, KEPUTUSAN MENTERI KESEHATAN REPUBLIK INDONESIA NOMOR HK.01.07/MENKES/187/2017 TENTANG FORMULARIUM RAMUAN OBAT TRADISIONAL INDONESIA. 2017.

[26] N. M. Ratminingsih, "Penelitian Eksperimental Dalam Pembelajaran Bahasa Kedua," Prasi, vol. 6, no. 11, pp. 3140, 2010.

[27] H. Sheikh, S. Sikder, S. K. Paul, A. M. R. Hasan, M. M. R. And, and S. P. Kundu, "HYPOGLYCEMIC, ANTIINFLAMMATORY AND ANALGESIC ACTIVITY OF PEPEROMEA PELLUCIDA (L.) HBK (PIPERACEAE)," J. Ethnopharmacol., vol. 91, no. 2-3, pp. 215-218, 2004, doi: 10.1016/s0378-8741(04)00029-7.

[28] D. Mayefis, H. Marliza, L. Mikrobiologi, S. Tinggi, I. Kesehatan, and M. Bunda, "UJI AKTIVITAS ANTIBAKTERI EKSTRAK DAUN SURUHAN ( Peperomia pellucida L . Kunth ) TERHADAP Propionibacterium acnes ANTIBACTERIAL ACTIVITY TEST OF SURUHAN LEAVES ( Peperomia pellucida L . Kunth ) AGAINST Propionibacterium acnes," vol. 2, no. 1, pp. 35-41, 2020.

[29] E. Sitorus, L. I. Momuat, and D. G. Katja, "AKTIVITAS ANTIOKSIDAN TUMBUHAN SURUHAN (Peperomia pellucida [L.] Kunth)," J. Ilm. Sains, vol. 13, no. 1, p. 80, 2013, doi: 10.35799/jis.13.1.2013.2116. 